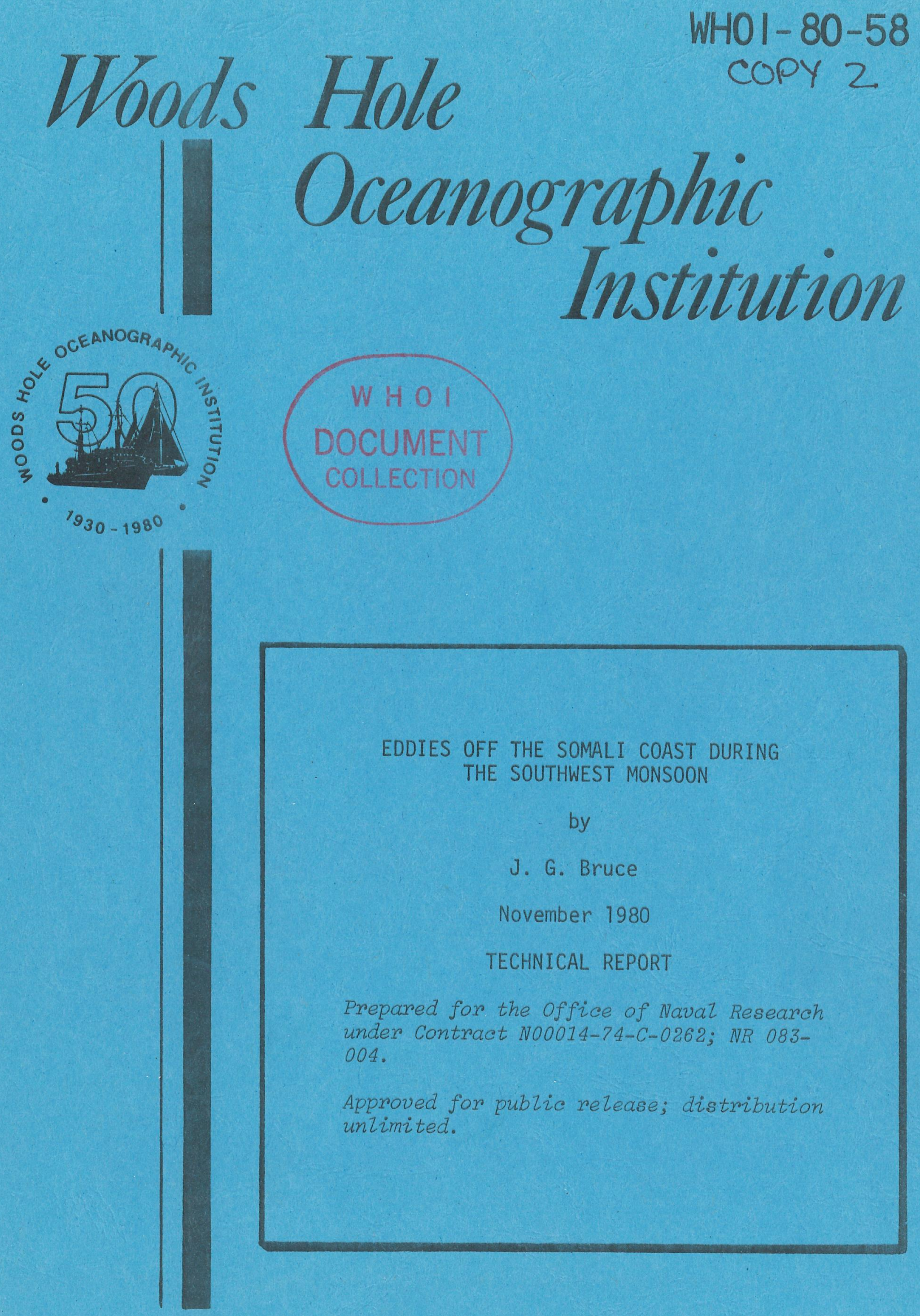

WWODS HOLE, MASSACHUSETTS 02543 
WHOI -80-58

EDDIES OFF THE SOMALI COAST DURING THE SOUTHWEST MONSOON

by

J. G. Bruce

WOODS HOLE OCEANOGRAPHIC INSTITUTION

Woods Hole, Massachusetts 02543

November 1980

TECHNICAL REPORT

Prepared for the Office of Naval Research under Contract N00014-74-C-0262; NR 083-004.

Reproduction in whole or in part is permitted for any purpose of the United States Goverment. In citing this report in a bibliography, the reference given should be to "Journal of Geophysical Research, Vol. 84, No. C12, December 20, 1979, pp. 7742-7748".

Approved for public release; distribution unlimited.

Approved for Distribution: Valentine Worthington, Chairman Department of Physical Oceanography 


\title{
Eddies off the Somali Coast During the Southwest Monsoon
}

\author{
J. G. BRUCE
}

\author{
Woods Hole Oceanographic Institution, Woods Hole, Massachusetts 02543
}

\begin{abstract}
The development and decay of the large eddy in the northern Somali Basin and its smaller associated eddies each southwest monsoon in the northwestern Indian Ocean has been monitored for four consecutive years by a time series of temperature sections obtained along the tanker sea lane across the Somali Basin. The evidence suggests that the large eddy first forms between $4^{\circ} \mathrm{N}$ to $12^{\circ} \mathrm{N}$ during late May and tends to remain approximately in this location throughout the entire southwest monsoon.
\end{abstract}

A series of temperature sections along the tanker sea lane (Figure $1 a$ ) off the East African and Arabian coasts has allowed us to observe the seasonal development of the large eddies which occur during the period of strong southwest monsoon winds in the northwestern Indian Ocean. For four consecutive years (1975-1978), the large 'prime' eddy described by Bruce [1968] was formed in the northern Somali Basin between approximately $4^{\circ} \mathrm{N}$ and $12^{\circ} \mathrm{N}$. I have called it the prime eddy because it appears to be the first to form in the region upon commencement to the southwest monsoon, it is considerably larger and more energetic than other eddies formed there during the year, and it has been observed to remain in this location at least three months after cessation of the southwest monsoon. It is first discernible from our sections in late May or early June in the near surface waters $(0-100 \mathrm{~m})$ and continues to intensify until late September or early October at the end of the southwest monsoon. The fully developed eddy is clearly evident as indicated by the depressed isotherms of the temperature sections in Figure 1. The horizontal dimensions across the prime eddy are 400 to $600 \mathrm{~km}$ with variations occurring during a single monsoon season [Bruce, 1970] as well as yearly differences which will be described here.

An eddy of smaller horizontal dimensions which appears to be associated with the prime eddy was found each year (19751978) off Socotra between $12^{\circ} \mathrm{N}$ and $15^{\circ} \mathrm{N}$. Also during some years such as 1976 (also 1970 [Bruce, 1973]) an eddy was observed south of about $5^{\circ} \mathrm{N}$ and adjacent to the southern boundary of the prime eddy and to the east African coast.

Our observations during several surveys within the last fifteen years indicate that the northeastward flowing alongshore current (Somali Current) is clearly part of the eddy field found each southwest monsoon off the Somali coast [Swallow and Bruce, 1966; Bruce, 1968, 1973]. The current diverges from the coast turning eastward about $9^{\circ} \mathrm{N}$ to $10^{\circ} \mathrm{N}$ each year and during some years also at $3^{\circ} \mathrm{N}-5^{\circ} \mathrm{N}$ forming a southern eddy. Farther offshore $\left(55^{\circ}-58^{\circ} \mathrm{E}\right)$, it turns southward and then back toward the shore. All past measurements known to the author indicate that during the SW monsoon, a clockwise 'warm' eddy (prime eddy) of this general description occurs within the Somali Basin. Pronounced upwelling with surface temperatures as low as $13^{\circ} \mathrm{C}$ [Warren et al., 1966] is found in the region where the strong coastal current turns offshore.

Our present program utilizes ships of opportunity (Exxon tankers) en route along the sea lane between the Persian Gulf and South Africa. We are able to obtain a temperature-depth $(0-450 \mathrm{~m})$ section with expendable bathythermograph (XBT) probes approximately every three weeks along essentially the

Copyright (C) 1979 by the American Geophysical Union. same track. The track location is extremely fortuitous in that it passes directly through the central region of the eddy field and thus provides an excellent means of monitoring the growth and decay of the eddies which are formed during each southwest monsoon. The measurements were obtained by special observers who were placed aboard at Cape Town, South Africa, and made a round trip to the Persian Gulf, thus obtaining two sections per trip. To date 40 sections have been completed. The closely spaced stations (20-30 km apart) necessary to observe the small scale features of the temperature structure essentially require a full time observer who was also needed to maintain good quality control of the data and record at each station wind velocity, ship's set by currents, surface salinity samples, etc.

With each of the sections shown in Figure 1 (which represent the fully developed southwest monsoon eddy system) is given a schematic representation of the circulation pattern of the near-surface water (upper $150 \mathrm{~m}$ ). This estimate is aided by previous surveys in this area [Bruce, 1968, 1970] during which time the structure of the eddies to the east and west of the tanker track was observed. A time sequence showing the development of the thermal structure of the eddies during the 1978 southwest monsoon is given in Figure 2. In late March no large scale horizontal gradients are evident in the upper thermocline whereas in the May section the prime eddy is clearly discernible between $5^{\circ} \mathrm{N}$ and $10^{\circ} \mathrm{N}$. During July and August (the periods of maximum wind strength) the development has intensified with a deepening of the mixed layer in the central regions of the prime eddy (centered approximately about $\left.8^{\circ} \mathrm{N}\right)$ and the Socotra eddy $\left(12^{\circ} \mathrm{N}\right)$. By December 1978 a relaxation of the eddy field is evident. During some years, however, the prime eddy is still discernible in the upper layer as late as January. Figure 3 indicates the prime eddy still to be present in the January $22-27$ section. At this time the succeeding northeast monsoon is nearly over.

Although the prime eddy is found each year within the northern Somali Basin, there are some differences from year to year. Probably the most evident is the formation of a southern eddy in 1976. The pattern in 1976 is similar to that found in 1970 [Bruce, 1973]. The coastal surface current turned offshore about $5^{\circ} \mathrm{N}$ and formed an eddy south of the prime eddy. Normally in the case of a single large eddy as observed during 1975 and 1977, the strong upwelling associated with the divergence of the coastal current from the coast occurs at approximately $9^{\circ} \mathrm{N}$ to $11^{\circ} \mathrm{N}$. When the southern eddy forms and becomes well developed as in 1970 and 1976, then strong upwelling also occurs at $4^{\circ} \mathrm{N}-6^{\circ} \mathrm{N}$.

Two other independent sets of observations during the 1976 southwest monsoon give evidence for this circulation pattern: 

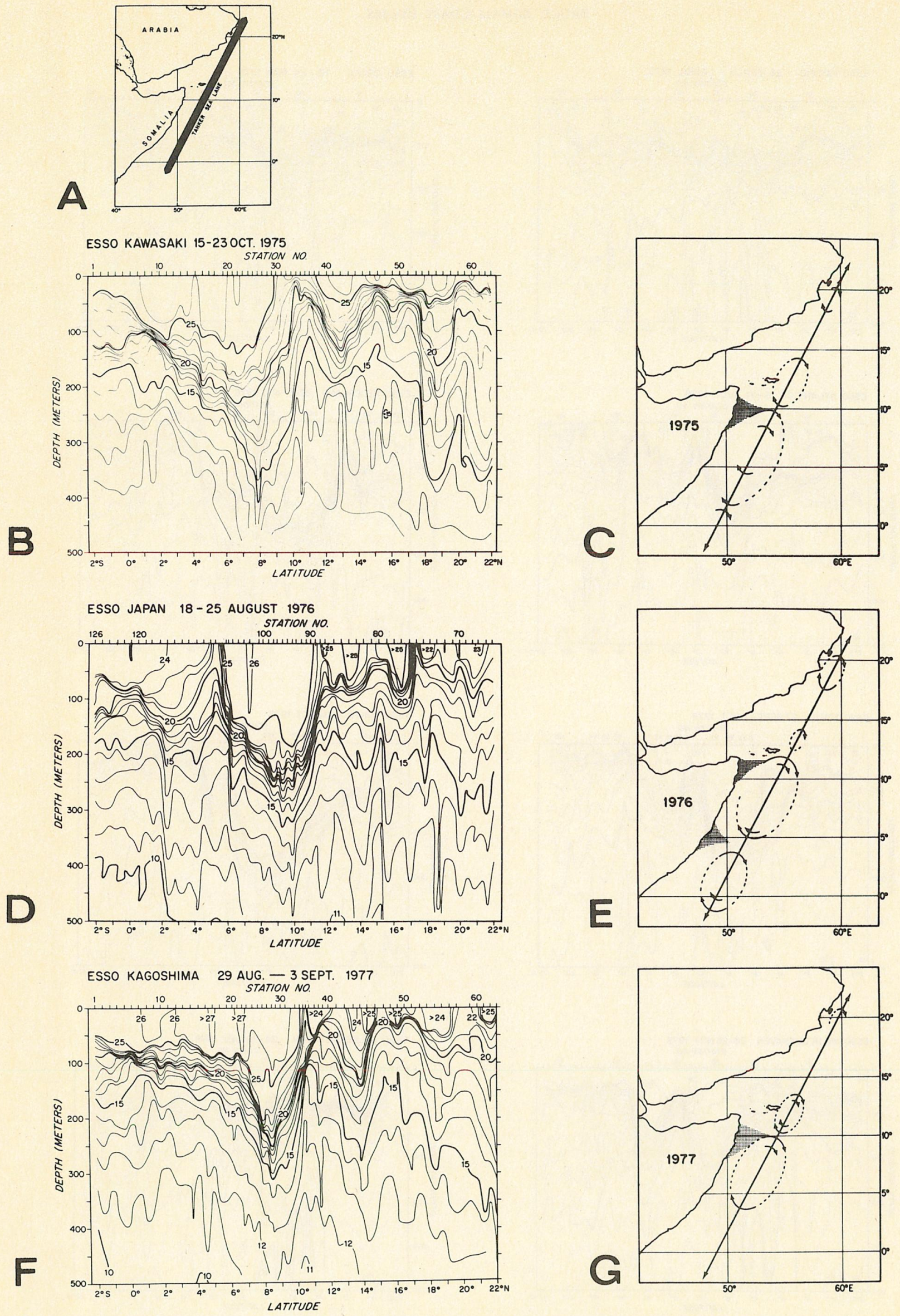

Fig. 1. (a) Sea lane used by tankers en route between Persian Gulf and Atlantic ports along which XBT sections are obtained. Temperature $\left({ }^{\circ} \mathrm{C}\right)$ sections along the tanker sea lane from XBT's for three successive southwest monsoons $(b, c)$ $1975,(d, e) 1976$, and $(f, g) 1977$. The large Somali prime eddy is clearly discernible $\left(4^{\circ} \mathrm{N}\right.$ to $\left.12^{\circ} \mathrm{N}\right)$ with the smaller Socotra eddy to the north (right). The schematic drawings indicate probable circulation pattern of the eddies and regions of upwelling (shaded triangular areas off Somali coast). 

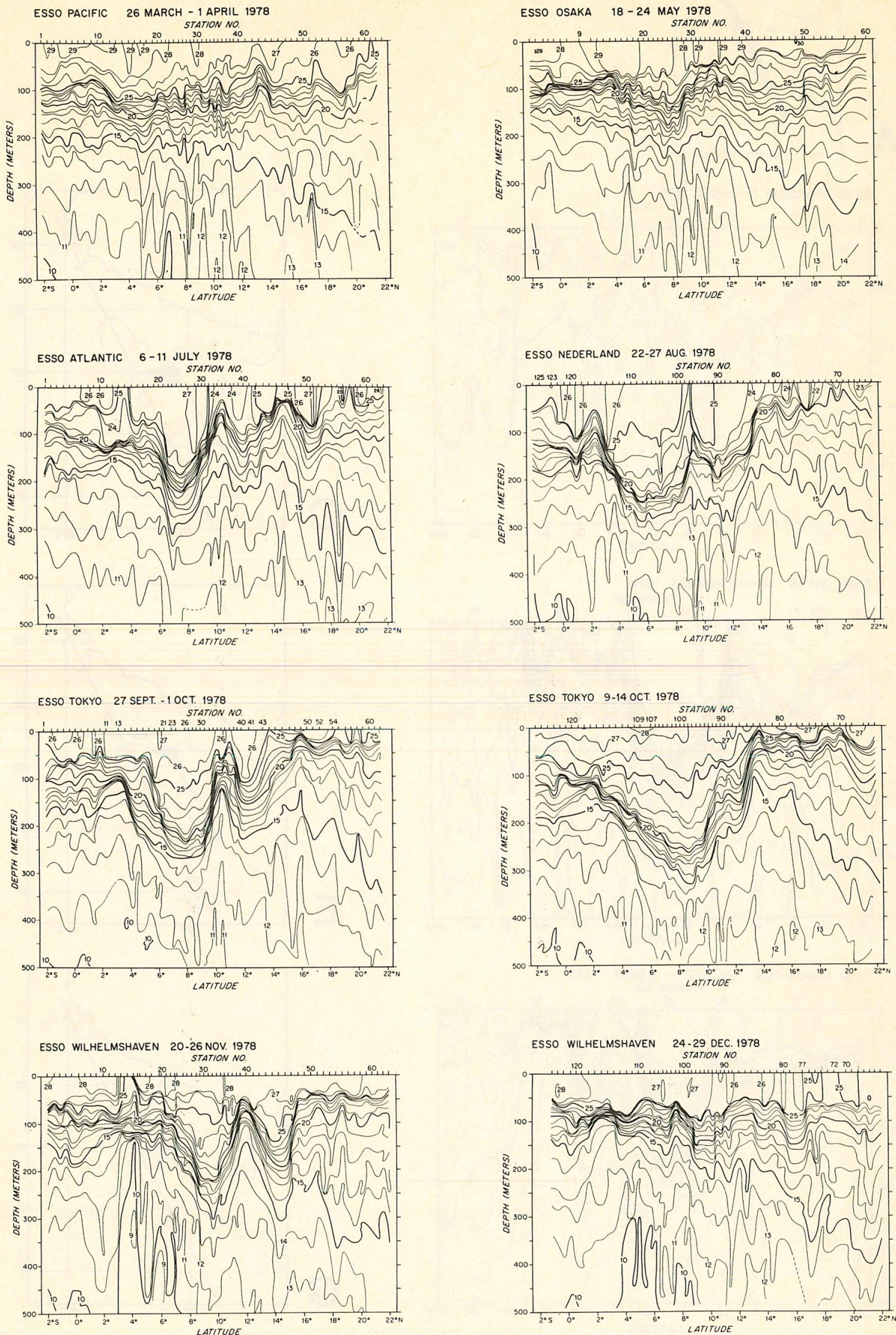

Fig. 2. 1978 temperature $\left({ }^{\circ} \mathrm{C}\right)$ sections along the tanker sea lane from XBT data obtained during period of southwest monsoon. 


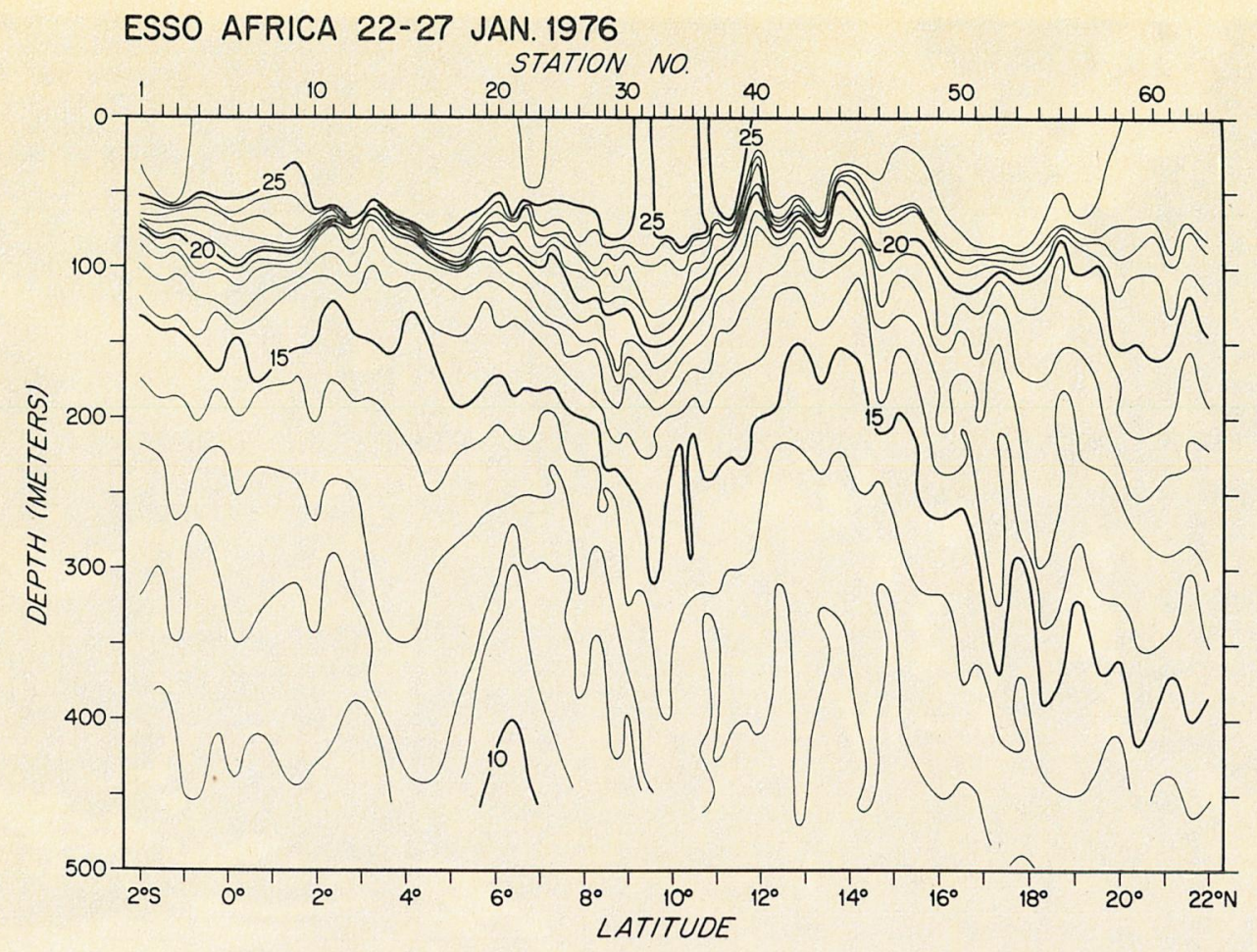

Fig. 3. Temperature $\left({ }^{\circ} \mathrm{C}\right)$ section from XBT stations along tanker sea lane during January 1976. Prime eddy generated during 1975 southwest monsoon appears between $6^{\circ} \mathrm{N}$ and $12^{\circ} \mathrm{N}$.

(1) Regier and Stommel [1976] using drifter buoys with satellite position fixing noted a clockwise eddy-like pattern in the region of the southern eddy (Figures $1 d$ and $1 e$ ); (2) satellite imagery from NOAA very high resolution radiometry (VHRR) on August 25, 1976 (Figure 4), was obtained contemporaneously with an XBT section by ESSO Japan (Figure 1d). The satellite picture clearly shows the pronounced upwelling near $5^{\circ} \mathrm{N}$ as well as near $10^{\circ} \mathrm{N}$ along the Somali coast.

Using other satellite IR data, Brown [1978] reported an area of cold water distributed along the Somali coast near $5^{\circ} \mathrm{N}$ for the 1976 southwest monsoon period. Further evidence for this mode of circulation during other years is given by Robinson [1960].

Judging from our present data, it appears that once the general pattern of circulation becomes established during the monsoon, then it tends to continue throughout the duration of the monsoon. For example, between late May and mid-October 1976, all eight of our tanker XBT sections obtained throughout this period indicate that both the southern eddy and prime eddy were present.

In 1975, 1977, and 1978 whereas a well-developed southern eddy was not evident, still there appear to be variations in the near surface $(0-100 \mathrm{~m})$ structure that suggest that some offshore flow might occur between $3^{\circ} \mathrm{N}$ and $5^{\circ} \mathrm{N}$. For example, along the October 19-23, 1975, section (Figure $1 b$ ) at $4^{\circ} \mathrm{N}$ $5^{\circ} \mathrm{N}$, there are small scale temperature gradients which suggest a weak eastward flow in the upper $100 \mathrm{~m}$. It seems possible that the returning onshore flow $\left(2^{\circ} \mathrm{N}-5^{\circ} \mathrm{N}\right)$ of the prime eddy might well affect changes in the alongshore current flow. Similar observations are described in laboratory scale models for fluidics research [Carbonaro et al., 1970].

Our time series of sections following the development of the eddy structure through the early stages of the southwest mon- soon (March through June) indicate that the prime eddy first forms between $5^{\circ} \mathrm{N}$ and $10^{\circ} \mathrm{N}$ in the Somali Basin, with the center at approximately $8^{\circ} \mathrm{N}, 53^{\circ} \mathrm{W}$. Our data do not suggest that the eddy is formed at the equator and then translates northeastward along the coast as postulated by the numerical models of Cox [1976] and Hurlburt and Thompson [1976]. There is evidence, however, that the northern boundary of the prime eddy and the southern eddy as well can shift as much as a degree of latitude as observed in 1964 [Swallow and Bruce, 1966; Bruce, 1973], and along the tanker sections during 1977 (from $8 \frac{1}{2}^{\circ} \mathrm{N}$ on June 1 to $9 \frac{1}{2}^{\circ} \mathrm{N}$ on June 30). Furthermore, our observations during 1970 indicated that the southern eddy appeared to merge with the prime eddy in September after its northern boundary had shifted from about $5^{\circ} \mathrm{N}$ to $6^{\circ} \mathrm{N}$ during August [Bruce, 1973]. During both 1977 and 1978, our observations indicate that the eddy is clearly evident in the near surface layers $(0-100 \mathrm{~m})$ as early as late May or early June.

The strong signal in the dynamic topography $\left(7^{\circ} \mathrm{N}-10^{\circ} \mathrm{N}\right)$ of the sea surface within the prime eddy is evident in Figure 5. The same T-S relationship for the Somali Basin during the southwest monsoon (a mean T-S curve determined by values obtained from previous surveys during the southwest monsoon period) was used for all these determinations shown. The density gradients that occur in the Somali eddies, as in the Gulf Stream, are largely a function of temperature. The pronounced downward slope of the surface topography to the north occurs between $8^{\circ} \mathrm{N}$ and $12^{\circ} \mathrm{N}$ with values on the order of $2 \times 10^{-3}$ dyn $^{-1}$ (about the same as found across the Gulf Stream at $\left.36^{\circ} \mathrm{N}\right)$. The volume transport of the prime eddy to the east offshore amounts to 38 to $42 \times 10^{6} \mathrm{~m}^{3} \mathrm{~s}^{-1}(0-400 \mathrm{dbar}$, relative to $400 \mathrm{dbar}$ ) with a comparable return flow inshore to the south between $4^{\circ} \mathrm{N}$ and $8^{\circ} \mathrm{N}$. To the north of the prime eddy, the Socotra eddy also occurs each of the four observa- 


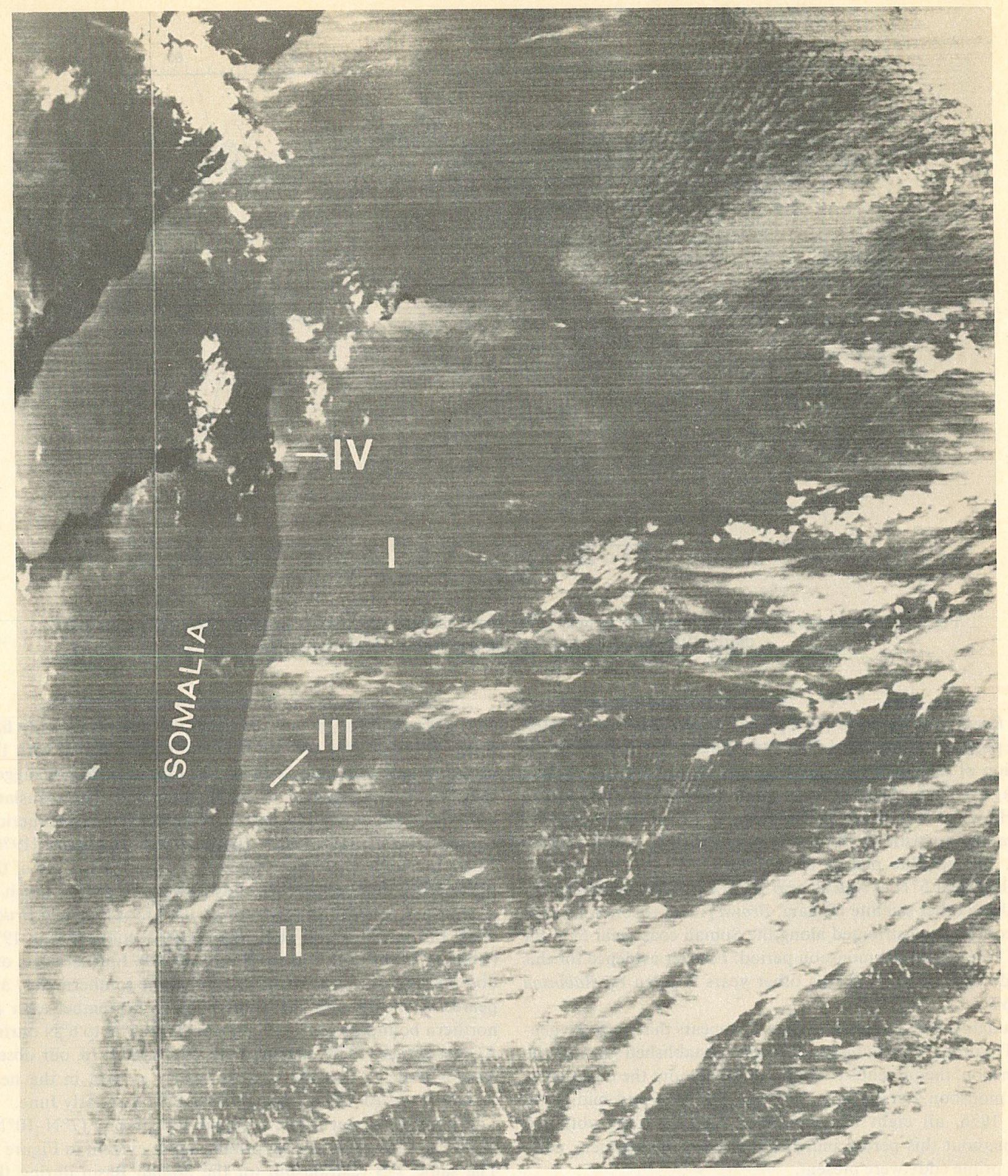

Fig. 4. The satellite imagery on August 25, 1976, was obtained at the same time as the XBT section in Figure $1 d$, and shows the prime eddy I, the southern eddy II, and the coastal upwelling associated with the divergence of the current from the coast, III at about $5^{\circ} \mathrm{N}$ and IV at $10^{\circ} \mathrm{N}$. Satellite imagery NOAA 4, orbit 8121 , VHRR August 25, 1976.

tion years (see Figures 2 and $5,11^{\circ} \mathrm{N}-15^{\circ} \mathrm{N}$ ) with transports on the order of 9 to $15 \times 10^{6} \mathrm{~m}^{3} \mathrm{~s}^{-1}$. During 1978 the temperature sections show that this eddy (center of eddy along sections is about $12^{\circ} \mathrm{N}$ ) was well developed during July, August, and September. The October 9-14 section suggests partial merging with the prime eddy at $11^{\circ} \mathrm{N}$ although in November it appears again to have clearly separated.

The near surface temperature and salinity characteristics of the western Indian Ocean, particularly in the region of the So- mali Basin, are changed considerably during the southwest monsoon as a result of several factors: the advection into the basin by the Somali Current of relatively cool and fresh South Equatorial Current water, high evaporation, advection of upwelled water (also relatively fresh and cool) off the Somali coast, vertical mixing resulting from the very large wind stress at the sea surface during the southwest monsoon, and horizontal mixing within the anticyclonic eddies. Within the upper $100 \mathrm{~m}$ along the tanker sea lane between $2^{\circ} \mathrm{N}$ and $12^{\circ} \mathrm{N}$ 


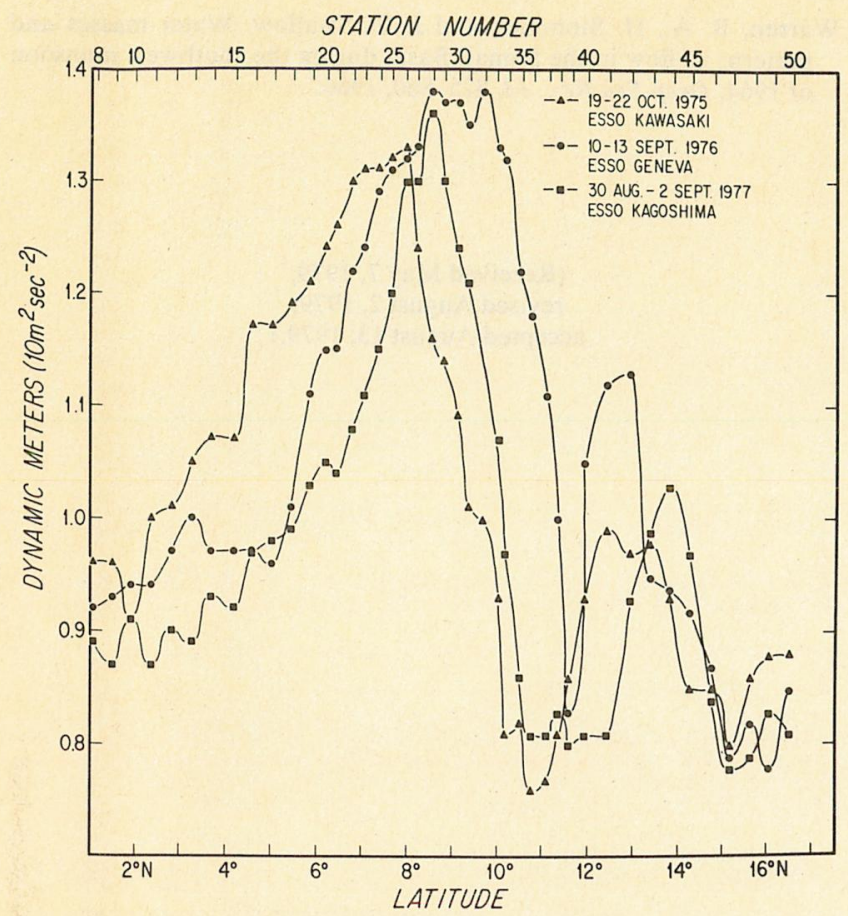

Fig. 5. Sea surface dynamic height during the southwest monsoons 1975, 1976, and 1977 constructed from XBT stations along the tanker sea lane (Figure la). For each year the strong signal of the prime eddy occurs from $8^{\circ} \mathrm{N}$ to $10^{\circ} \mathrm{N}$ with a deep trough to the north $\left(11^{\circ} \mathrm{N}-12^{\circ} \mathrm{N}\right)$ between it and the Socotra eddy $12^{\circ} \mathrm{N}-14^{\circ} \mathrm{N}$. Meansalinity from previous data in this region was used with XBT temperatures to determine the density values needed to produce these curves.

during the monsoon period (approximately three months) in 1976 and 1977 there was a heat loss of roughly $3 \times 10^{12} \mathrm{cal} /$ $\mathrm{cm}$ as determined from the XBT temperature stations. Now the area of the region influenced by entrainment within the eddy circulation where relatively good mixing is found [Bruce, 1968] extends roughly $400 \mathrm{~km}$ offshore. Thus the total heat loss of the area would be about $10^{20} \mathrm{cal}$ if the tanker section were considered representative of the area. The rate of heat loss is the same order of magnitude as that found in the western North Atlantic [Bunker and Worthington, 1976], although in the Somali region the loss occurs only over the monsoon period and is regained again in the interim spring warming period between the northeast and southwest monsoons.

Although there is a heat loss in the upper $100 \mathrm{~m}$ during the southwest monsoon, at the same time because of the deepening of the isotherms below the prime eddy there is a heat gain in the $100 \mathrm{~m}$ to $400 \mathrm{~m}$ layer. Thus the amount of actual heat lost to the atmosphere would be reduced by the transfer of heat to deeper layers. After the southwest monsoon as the eddy slowly weakens as shown by our series of XBT temperature sections, heat is released from these layers for three to four months after the monsoon. There is evidence from the sections that the prime eddy in fact was maintained from 1975 to 1976 through the northeast monsoon as suggested from earlier measurements by Bruce and Volkmann [1969], however, it is not clear that the continuity occurred between 1976 and 1977. At present our XBT observations extend only $450 \mathrm{~m}$ in depth, and it is clear that the horizontal gradient at the base of the prime eddy extends below this level.

Our data indicate that the temperature of the mixed layer of the equatorial water in the Somali Basin as well changes at the time when the eddy field is built up. Between $2^{\circ} \mathrm{N}$ and $2^{\circ} \mathrm{S}$ during the southwest monsoon the near-surface water along the tanker lane $\left(48^{\circ} \mathrm{E}-50^{\circ} \mathrm{E}\right)$ becomes cooler resulting in a corresponding drop in sea surface dynamic height (relative to 400 dbar) on the order of 0.10 to 0.15 dynamic $m$ in 1976 and 1977. In Figure 2 the reduction of temperature in the mixed layer can be seen to occur after the spring warming period in 1978. During the warming period (sections ESSO Pacific March 26-April 1 and ESSO Osaka May 18-24) the layer was $28^{\circ}$ to $29^{\circ} \mathrm{C}$. By July and August after the eddy field has developed the temperature dropped to $25^{\circ}$ to $26^{\circ} \mathrm{C}$ in this region. After the cessation of the southwest monsoon (ESSO Whilelmshaven November 20-26) the layer again warmed $\left(27^{\circ}\right.$ to $28^{\circ} \mathrm{C}$ ). It seems that this change might well influence the strength and/or direction of the equatorial undercurrent because a local slope of the sea surface which is negative westward might occur. Taft and Knauss [1967] found no evidence of the undercurrent on the western side of the Indian Ocean during the months of the southwest monsoon. It should be noted that although we have only surface salinity observations from these XBT sections, we find that the hydrographic data from this area indicates that the probable seasonal salinity variations would produce changes in the sea surface dynamic height of only about 0.005 dynamic $\mathrm{m}$.

Recent XBT data along the tanker sea lane for the initial part of the 1979 southwest monsoon although not yet analyzed indicates that during the first week of July 1979 the prime eddy appears to be located between $5^{\circ} \mathrm{N}$ and $10^{\circ} \mathrm{N}$ and a southern eddy has developed south of $5^{\circ} \mathrm{N}$. The circulation pattern appears to be similar to that of 1976 (see Figures 1d and $1 e$ ). The surface temperature reduced by upwelled water advected offshore by the prime eddy is $22.1^{\circ} \mathrm{C}$ at $9^{\circ} 40^{\prime} \mathrm{N}$ and along the northern boundary of the southern eddy is $21.4^{\circ} \mathrm{C}$ at $4^{\circ} 35^{\prime} \mathrm{N}$.

Acknowledgments Supported by the Office of Naval Research under contract N00014-74-C-0262, NR 083-004. Especial thanks are due to Exxon Corporation for their considerable help in allowing us to use their tankers for these XBT measurements and to the University of Cape Town Oceanographic Department staff (J. K. Mallory and E. S. W. Simpson and observers L. Wolhuter, M. Sangmeister, and M. Broad) for their large effort in the data acquisition. Contribution 4303 from the Woods Hole Oceanographic Institution.

\section{REFERENCES}

Brown, O., Satellite sea surface temperature observations in the equatorial Atlantic and western Indian Oceans, INDEX: Occas. Note 9, Ocean Sci. Center, Nova Univ., Dania, Fla., 1978.

Bruce, J. G., Comparison of near surface dynamic topography during the two monsoons in the western Indian Ocean, Deep Sea Res. 15(6), 665-677, 1968.

Bruce, J. G., Notes on the Somali Current system during the southwest monsoon, J. Geophys. Res., 75(21), 4170-4173, 1970.

Bruce, J. G., Large scale variations of the Somali Current during the southwest monsoon, 1970, Deep Sea Res., 20(9), 837-846, 1973.

Bruce, J. G., and G. Volkmann, Some measurements of current off the Somali Coast during the northeast monsoon, J. Geophys. Res., 74(8), 1958-1967, 1969.

Bunker, A. F., and L. V. Worthington, Energy exchange charts of the North Atlantic Ocean, Bull. Amer. Meteorol. Soc., 57(6), 670-678, 1976.

Carbonaro, M., P. E. Colin, and D. Olivari, The deflection of a jet by a crossflowing stream and its application to anemometery, von Karman Inst. for Fluid Dynamics, Rhode-Saint-Genese, Belgium, 1970.

Cox, M. D., Equatorially trapped waves and the generation of the Somali Current, Deep Sea Res., 23(12), 1139-1152, 1976.

Hurlburt, H. E., and J. D. Thompson, A numerical model of the Somali Current, J. Phys. Oceanogr., 6(5), 646-664, 1976. 
Regier, L., and H. Stommel, Trajectories of INDEX surface drifters, INDEX: Occas. Note 5, Ocean Sci. Center, Nova Univ., Dania, Fla., 1976.

Robinson, M. K., Indian Ocean vertical temperature sections, Deep Sea Res., 6(3), 249-258, 1960.

Swallow, J. C., and J. G. Bruce, Current measurements off the Somali Coast during the southwest monsoon of 1964, Deep Sea Res., 13(5), 861-888, 1966.

Taft, B. A., and J. A. Knauss, The equatorial undercurrent of the Indian Ocean as observed by the Lusiad Expedition, Bull. Scripps Inst. Oceanogr., 9, 1-163, 1967.
Warren, B. A., H. Stommel, and J. C. Swallow, Water masses and patterns of flow in the Somali Basin during the southwest monsoon of 1964, Deep Sea Res., 13, 825-860, 1966.

(Received May 7, 1979; revised August 2, 1979; accepted August 13, 1979.) 


\section{MANDATORY DISTRIBUTION LIST \\ FOR UNCLASSIFIED TECHNICAL REPORTS, REPRINTS, AND FINAL REPORTS \\ PUBLISHED BY OCEANOGRAPHIC CONTRACTORS \\ OF THE OCEAN SCIENCE AND TECHNOLOGY DIVISION \\ OF THE OFFICE OF NAVAL RESEARCH}

(REVISED NOVEMBER 1978)

1 Deputy Under Secretary of Defense

(Research and Advanced Technology)

Military Assistant for Environmental Science Room 3D129

Washington, D.C. 20301

Office of Naval Research

800 North Quincy Street

Arlington, VA 22217

3 ATTN: Code 483

1 ATTN: Code 460

2 ATTN: 102B

1 CDR J. C. Harlett, (USN)

ONR Representative

Woods Hole Oceanographic Inst.

Woods Hole, MA 02543

Commanding Officer

Naval Research Laboratory

Washington, D.C. 20375

6
12 Defense Documentation Center Cameron Station

Alexandria, VA 22314

ATTN: DCA

Commander

Naval Oceanographic Office NSTL Station

Bay St. Louis, MS 39522

1 ATTN: Code 8100

1 ATTN: Code 6000

1 ATTN: Code 3300

1 NODC/NOAA

Code D781

Wiscons in Avenue, N.W.

Washington, D.C. 20235 


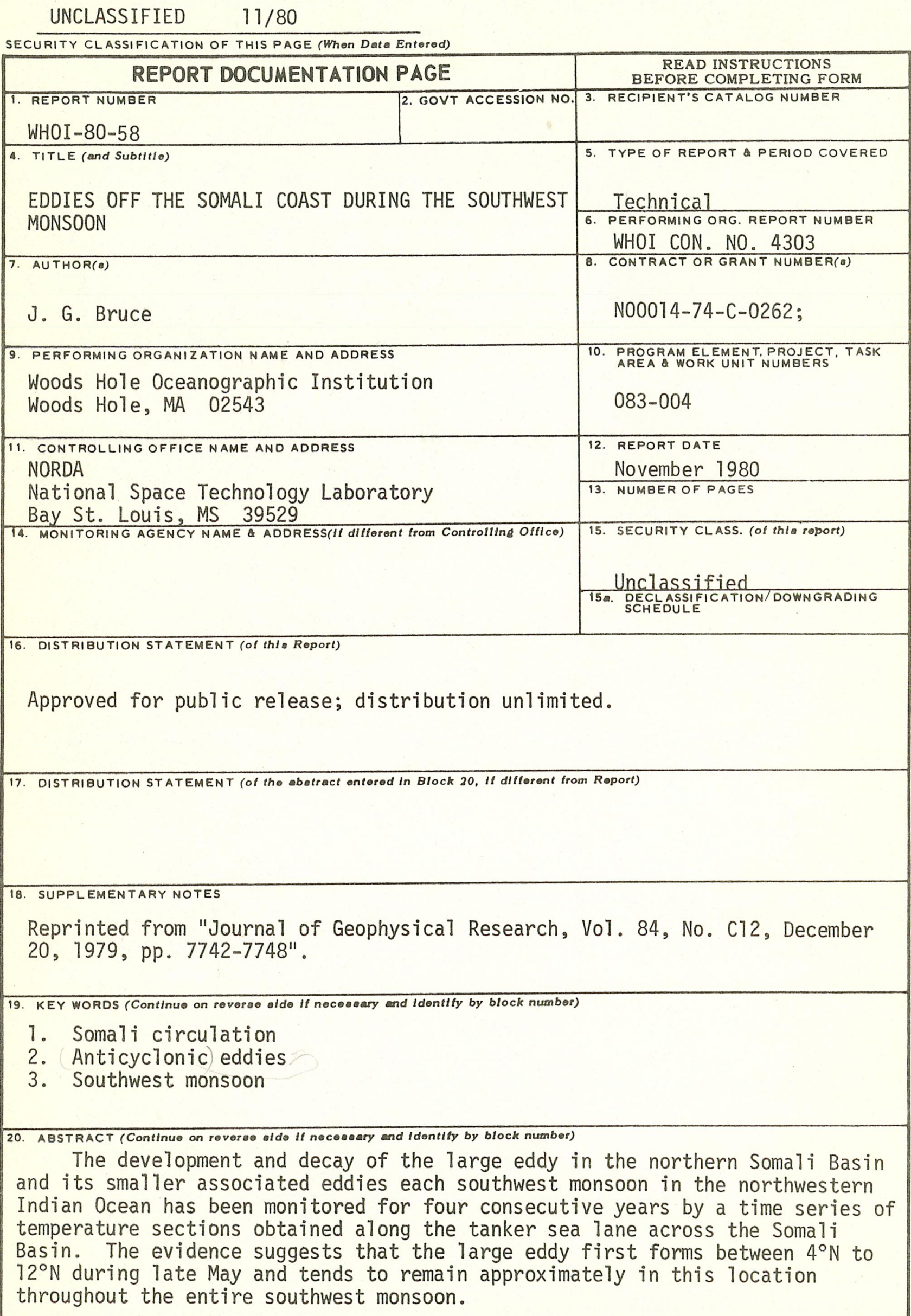




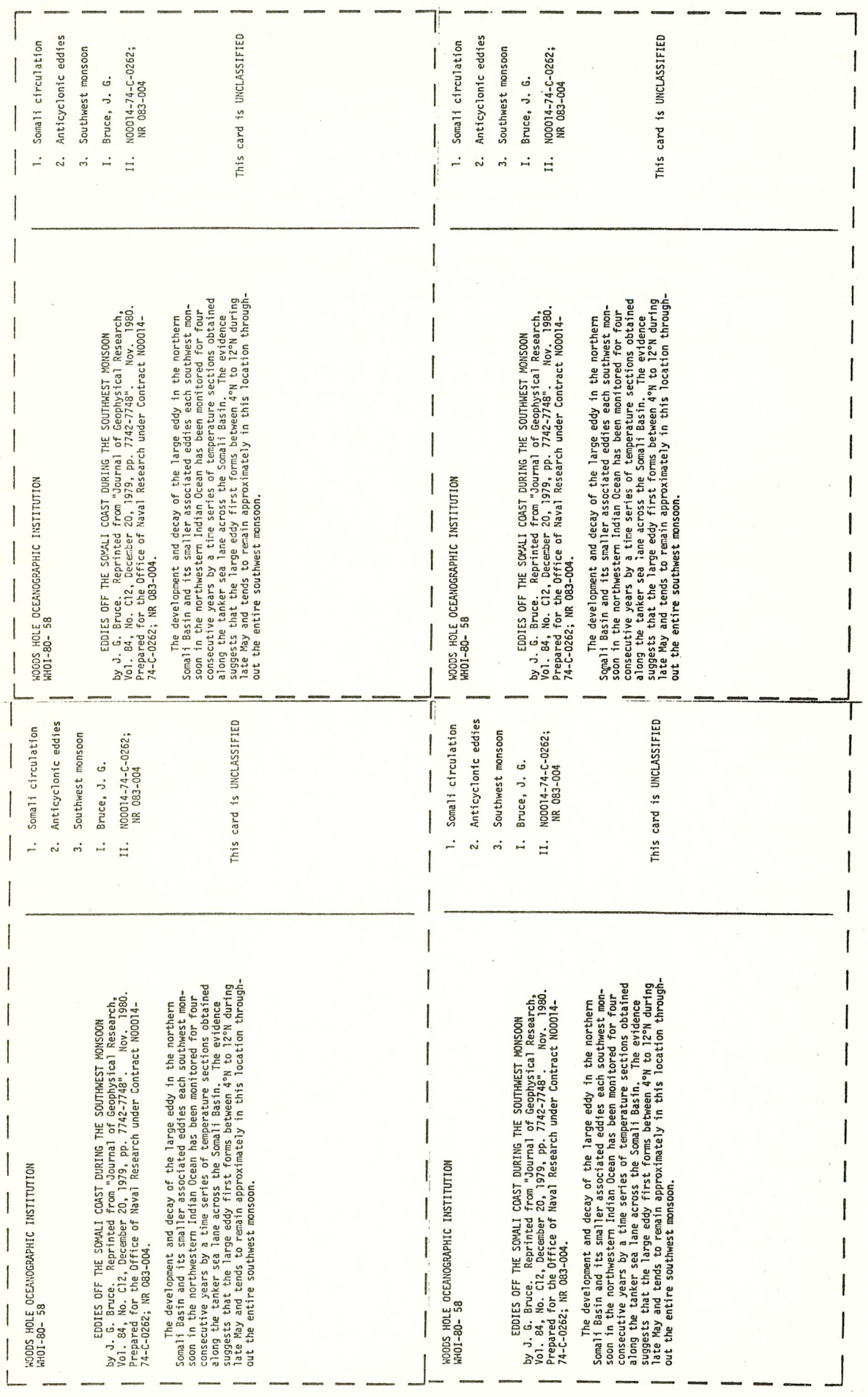

